This article was downloaded by: [James Cook University]

On: 19 August 2010

Access details: Access Details: [subscription number 917270735]

Publisher Routledge

Informa Ltd Registered in England and Wales Registered Number: 1072954 Registered office: Mortimer House, 3741 Mortimer Street, London W1T 3JH, UK

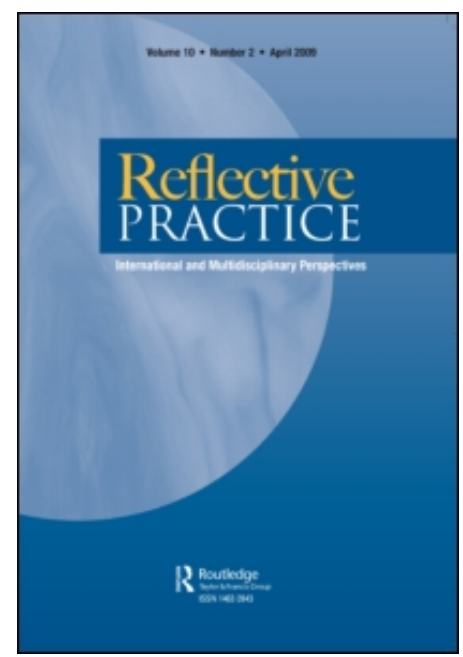

\title{
Reflective Practice
}

Publication details, including instructions for authors and subscription information:

http://www.informaworld.com/smpp/title content=t713443610

\section{Making reflection public: using interactive online discussion board to enhance student learning}

Sharn Rocco ${ }^{\mathrm{a}}$

School of Education, James Cook University, Townsville, Queensland, Australia

Online publication date: 18 June 2010

To cite this Article Rocco, Sharn(2010) 'Making reflection public: using interactive online discussion board to enhance student learning', Reflective Practice, 11: 3, 307 - 317

To link to this Article: DOI: $10.1080 / 14623943.2010 .487374$

URL: http://dx.doi.org/10.1080/14623943.2010.487374

\section{PLEASE SCROLL DOWN FOR ARTICLE}

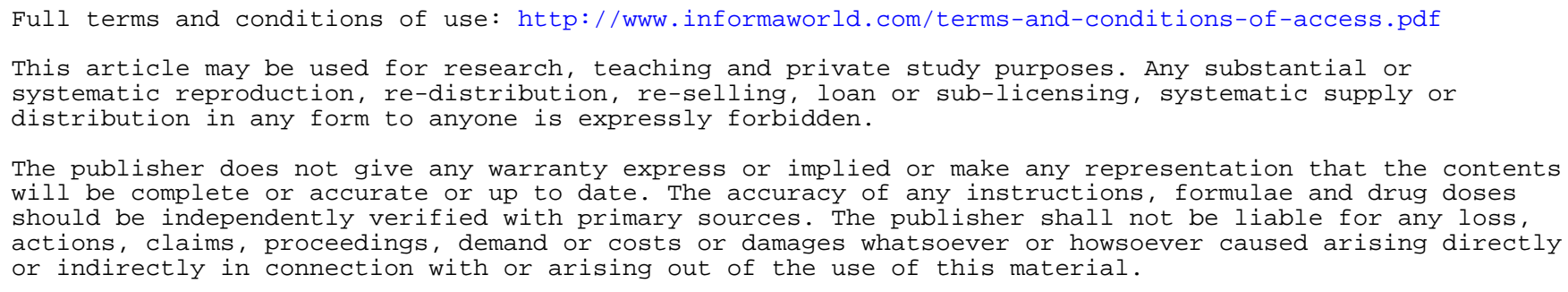

The publisher does not give any warranty express or implied or make any representation that the contents will be complete or accurate or up to date. The accuracy of any instructions, formulae and drug doses should be independently verified with primary sources. The publisher shall not be liable for any loss, actions, claims, proceedings, demand or costs or damages whatsoever or howsoever caused arising directly or indirectly in connection with or arising out of the use of this material. 


\title{
Making reflection public: using interactive online discussion board to enhance student learning
}

\author{
Sharn Rocco* \\ School of Education, James Cook University, Townsville, Queensland, Australia
}

(Received 26 March 2010; final version received 21 April 2010)

\begin{abstract}
The account of teacher education pedagogy presented here suggests that reflective practice in the form of reflective online letter writing has the potential to move conversations towards an epistemological shift that values multiple perspectives and builds confidence and competence for engaging in reflection and professional dialogue. This paper focuses on the requirement for reflection within a teacher education course in a regional Australian university that blends online and faceto-face teaching and learning. What is of particular interest is how the possibilities and enabling limits of asynchronous, online discussion can scaffold student engagement with course content and with one another in ways that enhance their willingness and ability to read, write and interact reflectively. The paper reflects on how the move to online reflection and to composing reflections as a letter to a critical friend made this, more often private, assessment driven, process interactive and open to a wider audience. Making reflection public seems to have had a positive impact on the quality and style of reflection and interactions; and on student commitment to imagining possible futures as agents of change within classrooms and schools.
\end{abstract}

Keywords: reflection; online; reflective writing; teacher education; pedagogy

\section{Introduction}

In a review of relevant literature, Killen (2007, pp. 92-94) claims that 'the benefits of reflection are considerable and tangible' for teachers and learners. Reportedly, reflective teachers have better interpersonal relationships with students, higher job satisfaction and feelings of self-efficacy, are more able to talk and write about their experiences, are more likely to grant students autonomy, use inquiry methods and expect themselves and their students to act ethically. It is not surprising then that reflection in various forms has become a salient aspect of many teacher preparation courses. In Australia and elsewhere, reflective practice is becoming enshrined in professional standards for teachers that are driving quality assurance, course accreditation and teacher selection procedures (Queensland College of Teachers (QCT), 2007; Victorian Institute of Teaching, 2005).

Requiring students to reflect raises various philosophical and pedagogic concerns. Lynch (2000, p. 26) asserts that reflection is 'often claimed as a methodological virtue and source of superior insight' that deflects potential criticism, pointing out that reflective practice, in an array of formats, is a largely undisputed aspect of teacher

*Email: sharn.rocco@jcu.edu.au 
education. Hobbs (2007) questions whether reflective practice can 'retain validity as genuine reflection' when it is an assessable component of coursework. Klein (2008, p. 111) argues that conceptions and practices of reflection that are derived from this state of play are didactic and do not 'enable teachers to think contemplatively or imaginatively about teaching'. She also contends that current practices of reflection do not engage teachers in asking questions and that these conditions support and represent an anti-intellectualism in teacher-education. Gleaves, Walker and Grey (2008) argue that reflective journal or diary writing is deliberate but not usually didactic or strategic. These concerns should be noticed by teacher educators - that reflective practice by virtue of becoming 'usual practice' and enshrined in teacher professional standards, is at risk of becoming taken-for-granted, superficial, bureaucratised and sanitised. Referring to the work of Lynch (2000, p. 36) Husu, Toom and Patrikainen (2008, p. 38) point out, 'what teacher reflection can do and what it can reveal all depend upon "who does it and how they go about it"".

This paper describes how the author incorporated reflection into conventional face-to-face pre-service teacher education coursework using an asynchronous online discussion board. The curriculum decisions and pedagogy described and reflected throughout the paper were directed towards integrating reflective practice into teacher education in ways that position students to read, write, interact and recall reflectively. Mindful that not everyone is predisposed to reflection (Hobbs, 2007), the design of learning tasks focused on scaffolding authentic experience and practice. The intention was to increase proficiency and activate willingness to reflect on course content and processes in ways that connected to professional practice. Making reflection public and interactive by posting to an online discussion board enabled the task design to acknowledge that today's learners want to engage creatively, work collaboratively, share information and attain celebrity (McLaughlin $\&$ Lee, 2008). The reflexive approach taken in the research, learning and teaching discussed is guided by socio-cultural and post-structural perspectives that value learning and the production of knowledge as always in process, interdependent and open to contestation.

The data displayed to illustrate and punctuate the description of the design and implementation of the reflective task are extracted from student reflections created as weekly online letters and replies posted to the course discussion board forum. From two consecutive offerings of the course, 34 of the 140 students enrolled consented to their weekly online letters being used for research purposes. Exemplars and extracts from the letters displayed throughout the paper are selected as representative of the participating cohort. As such, they are not identified or differentiated by student name or pseudonym. No two examples from the data are by the same student. Each extract is referenced noting whether it was written as a letter or reply, in what week of the course it was written and in which offering, e.g. (Extract from letter, Week 1:1).

All the respondents, except one, were female and ranged in age from 18 to 39 years of age. This gender and age distribution reflects the prevailing feminisation of teaching. Few males choose teaching as a post-school career path and increasing numbers of mothers who choose to enter teacher education courses after their children begin school underscore the feminisation of the profession. Many students experienced the requirement for regular online reflection as going 'against the grain' of usual practice and the lathe was not always sharp or accurately guided. Students and teacher were faced with unfamiliar expectations and ways of teaching and learning that are sometimes, and for some more than others, disorienting. Students were expected to reflect 
and to engage in dialogues that make links, navigating the unchartered space between categories of meaning and identity such as personal and professional, past and present, learner and teacher, public and private, rational and emotional, competitive and collaborative that, in the absence of 'critical-dialectical discourse', are more often mutually exclusive and hierarchical (Mezirow, 2003). Anonymous student feedback ranked the subject across the extremes from 'outstanding' to 'completely unacceptable'. The quality of the letters made available for research purposes suggests that consenting students were among those who ranked the experience more positively.

This paper is organised in five sections. This section has set the scene for the paper, and what follows should be read in light of the conditions, intentions, claims and concerns addressed. The next section focuses on how the design of and online reflective task can invigorate conventional face-to-face teaching strategies and student engagement. The following section reflects on the decision to circumscribe choice as a strategy for promoting dialogue and building relationships between students. The next section considers how reading and writing are critical to the success of education and of reflection. It addresses some of the challenges faced by teachers and students and how the design and demands of regular online reflection can mitigate for effective engagement with texts and with each other. The final section offers some conclusions for further reflection and contribution to the on-going debate surrounding why and how reflection is and can be effectively incorporated into course work for pre-service teachers.

\section{Invigorating conventions: blending online reflection with face-to-face teaching}

Dear critical friend,

This week's lecture introduced me to the concept of 'usual practice'. This got me thinking about the kinds of things that I see when I am in the classroom. In many classrooms I have witnessed the teacher standing in front of the class and the students sitting and listening, writing, answering rhetorical questions and having no opportunity to talk to their peers. I realized this is NOT how I want to teach. (Extract from letter, Week 1:1)

By the time students enter the course or 'subject' under discussion here, they have had at least two years of university study. They have foundational knowledge of theories of learning and teaching, repeated experience of being expected to attend lectures and tutorials, to read selected literature relevant to specific topics and use essential elements of the online learning system, including the discussion board platform referred to here. They have some experience as pre-service teachers and years of experience as students in classrooms attending school. They 'know' or at least have been told and read that collaboration and reflection are effective processes for classroom and professional learning. They 'know' or at least have been told and read that assessment is most effective when it is 'authentic' - when there is a real audience for the work produced and when learning occurs in the process of its production. Incorporating the requirement for regular reflective writing into the pedagogy and assessment is intended to activate and build on this learner knowledge, experiences and relevant, assumed and explicit competences. At the same time, the reflective writing task is designed and intended to position students to resist the sway of 'usual practice' that often leads them to teach as they were taught rather than as they were taught to teach (Freidus, 1998). Struggling against the tendency to teach as we were 
taught requires an awakening of reflective consciousness, an awareness of our habitual patterns and their effects.

As is evident in my descriptions and examples of data throughout this paper, much of the 'who does what and how they go about it' - in terms of course structure and content - conforms to what might be considered 'usual practice' in higher education. In an effort to activate and build on student prior learning and competences, these conventions were enacted with minor but critical pedagogical turns. Students are required to read, but each week there is a range of relevant readings from which to choose. Students were encouraged to reflect by focusing their letter on a particular aspect of interest from the readings they selected and by making relevant links to their prior learning and experience. Similarly, students are asked to include reflection on particular relevant points of interest or activity from lectures and tutorials. These choices were intended to scaffold students to shift the style of their writing from summative to reflective and to model how, within conventional modes of teaching, choice can be integrated to individuate teaching and learning and value diversity. The implementation of these intentions was supported by the requirement to compose their reflection as a letter to a critical friend. These seemingly minor but critical pedagogical turns were an attempt to face the challenge 'to enable self-direction, knowledge building and learner control by providing options and choice while still supplying the necessary structure and scaffolding' (McLaughlin \& Lee, 2008, p. 17):

Dear critical friend,

The life of a teacher is an adventurous one. 'Teaching is highly personal-an intimate encounter. The rhythm of teaching involves a complex journey, a journey of discovery and surprise, disappointment and fulfilment', (Bill Ayres in Hill, Stremmel, and Fu, 1993; Hill, Stremmel \& Fu, 2005, p. 28). ... I have grown a new passion and desire to not just become a teacher, but to better the lives of society's children and expose them to a world of endless inquiry and discovery through learning. My journey has started, and this subject has taught me to be a better teacher and more importantly a better person. ... to take on board self-reflection and see its importance in being critical of your actions in order to always better the situation. ... I have learnt that in teaching especially, we make mistakes, but to have an open mind to always better the situations will only reap positive outcomes. ... to move away from usual practices and critically reflect ... After one lecture my life turned around, and the habit of constantly fault finding personally and in others stopped and the ability to change my habit of the mind allowed me to see my profession and my personality change for the better. (Extract from letter, Week 13:1)

The two examples of data displayed above that bookend the 13-week course, suggest the transformative possibilities of scaffolded, interactive, asynchronous, reflection. Weekly letters and replies, informed by flexible course content that supports student understanding of the process, engaged students in reflecting and dialoguing points of personal, professional interest encountered in, and/or informed by, lectures and readings. Going digital appeared to activate the essential relational and public quality of learning (Brookfield, 1995; Dewey, 1933; Ukpokodu, 2008). The reflective content of the data suggests that combining the form of traditional letter writing with online learning technologies positioned students to experience and explicate the tentative and transformative possibilities of learning through reflection. Making reflections public and composing reflections as a letter to a critical friend facilitated the relational aspects of knowledge building and of collegiality: 
Thanks for being my critical friend this week.

I've just finished the Littky (2002) reading and am all fired up to 'Make it happen' (pardon the pun). This reading suggests that a school be viewed as a 'living organism' (p. 185) and to me that A. incites the notion of all components functioning together as a cohesive whole, and B. the 'living' aspect foregrounds the notion of constant change. Further, it encourages me to 'break the rules' (p. 195) and take risks in my education (and teaching) to ensure that I am not just 'sticking to old patterns in new situations' (p. 189). I find this kind of reading in our course exciting and refreshing and feel that finally we are getting more 'to the guts of it' by reflecting and formalising the first draft of our teaching philosophy....

Further, Poppo (2006) advocated the interconnectedness of life. We don't exist in a vacuum, we are interdependent and this is vital for a child's education firstly so that they see 'the big picture' (how they fit into and are affected by the world). ... I think for me a key to this idea of reflection is that in my writing about and recognising my feelings I am more able to recognise them in others and this helps in my interactions with them. I know that some things that I write in my journal surprise me because I think to myself, 'I never knew that I felt that way', but there it is in my writing and I get to get on with my day and think about that. This idea of the need for teachers to possess self-knowledge is talked about in the Bowman reading if you are interested. ... Go forth and ponder!! (Extract from reply, Week 3:2)

\section{Choices and relationships: making students response-able}

Sometimes offering choice is not the most effective scaffold for promoting critical learning and openness. In the first offerings of this redesigned task for online reflection, preceding the two from which the data are drawn for this paper, students formed self-selected pairs and made a commitment to respond to each other throughout the semester. Unsurprisingly, their choices of 'critical friend' mirrored established social friendships. Letters tended to be summative rather than reflective and only cursory and complimentary attention was paid to intellectual content when responding to their 'critical friend', such that interactions rarely moved beyond 'talking nice' (Gunnlaugson, 2007). Contrary to my assumption that pairing with a known other within an established relationship of trust would move dialogue more quickly into debate and critically reflective dialogue, interactions were mostly unproductive in establishing substantive or critical dialogue. In retrospect it seems that established relationships meant established discursive parameters - ways of speaking and being in the world, and that disrupting these might threaten the relationship. I failed to account for how 'the way that we perceive others see the world, and our being in that world, affects the confidence with which we take up or resist particular practices and discourses and how openly we imagine possible ways of being and belonging' (Rocco, 1999, p. 197). My reflections suggested that when there are no preconceptions and no established relationship to protect or circumscribe what can be said; students might be motivated towards establishing a relationship in which they positioned themselves as informed, informative and responsive - confident and articulate in presenting their views.

To avoid the pitfall of regressing to socially supportive and intellectually shallow correspondence that I had noticed when students self-selected a critical friend, the students from whose letters and replies the data for this paper were drawn, were paired each week with someone in their tutorial group mutually acknowledged as unfamiliar. The rationale for this strategy was made explicit to students. They were encouraged to see its relevance to the professional challenge that teachers confront when expected to 
describe and justify their practice to unfamiliar colleagues and parents. As with the various pedagogical strategies employed to engage students with this online reflective writing task, readings were provided to inform their reflection on the learning experiences encountered. Various activities were used during tutorials to pair students as 'critical friends':

Dear critical friend,

I thought the 'get to know a stranger' workshop activity raised my awareness of how I make immediate assumptions about others. ... by asking that we focus on something that interested us about the 'stranger', this activity connected with Killen's idea of reflection as a 'form of inquiry' (Killen, 2007, p. 92). ... I attempted to observe not only the other students but also myself and my reactions to them (reflection in action) I found this quite tricky but rewarding as it illustrated for me an aspect of the reading relating to Schön's (1983) idea of frame. (Extract from letter, Week 2:2)

Many students have had negative experiences of group work that can be ameliorated by asynchronous discussion that enables equitable, personalised contributions from each participant (Paulus \& Roberts, 2006). The guidelines for writing reflective letters and replies encouraged students to express feelings, to describe and analyse their emotional response to relevant experiences and readings. Creating a personal frame for reflection can open 'curriculum to make room for love, emotions, creativity, spirituality, and aesthetics because these all influence how priorities are set, and how the world is interpreted' (O'Hara, 2006, p. 114). Students expressed surprise that the 'feeling' element of learning was given credence. As one student commented in her first letter: 'WOW, we are actually asked how we feel. Instead of learning about theories, classroom issues and school curriculum, we are reflecting on thoughts and feelings that will eventually guide us in our philosophy and practice'. Of course it was not 'instead of', it was 'as well as'. For meaningful and purposive learning to take place, 'students clearly need educating in the importance and processes of critical reflection in every sense - cognitive, emotional and experiential' (Gleaves, Walker \& Grey, 2008, p. 230). Relationships are the warp and weft that form the fabric of education. Exchanging personally framed reflective letters and replies with others who were unfamiliar positioned students to broaden their experience and to recognise the diversity in ways that seemingly built confidence and competence and encouraged some students to invigorate their ways of thinking about teaching and learning as well as about each other and self:

Dear critical friend,

I am rather excited about writing letters and receiving responses. I believe I will benefit greatly from hearing your perspectives in regard to my enquiries and hope you will also benefit from my responses to yours.

Firstly, I share your feelings of resistance to such introduction activities as the one we participated in during the workshop. Despite my initial hesitation, reflecting upon this activity I feel grateful that we were pushed out of our comfort zones. Without this, I may not have had enough confidence to introduce myself to peers. Additionally, I now feel more relaxed knowing something quirky about the other students in our class. How interesting that one of our peers has pet lizards. I wonder if they are the same breed as my lizards? How do you feel after having participated in this introduction activity? If you are still feeling hesitant towards such activities or perhaps you should re-visit the lecture notes and re-read the poem written by Guillaume Apollinaire. 
'Come to the edge', she

said. 'We are afraid',

they said. 'Come to the

edge', she said. 'We are

afraid', she said. They

came to the edge.

She pushed them and they flew.

I find it helpful in understanding the reasons why lecturers and tutors encourage us to participate in such activities. ... (Reply, Week 2:2)

\section{Reading and writing: the core business of reflection and education}

As Hobbs (2007) points out, not everyone is predisposed to reflection. Becoming critically self-aware requires practice, intellectual engagement and purpose. It requires regular reading and writing. The challenge for teacher educators is to position students to experience how reflective writing impacts their learning about themselves and others as learners in ways that can develop skills and dispositions for incorporating reflection into their personal, professional repertoire of practice. This challenge is compounded with that of ensuring students make time for reading and valuing relevant literature. Making the reflective writing task assessable, and requiring reflective letters to synthesise and analyse pertinent elements of selected readings to illustrate and substantiate claims, compelled students to purposefully engage with the relevant literature as integral to practicing reflection and engaging in professional dialogue:

Dear critical friend,

I think that Bowman (1989) was suggesting that teachers need to develop two distinct types of knowledge: formal, based on theories, statistical evidence and experiments and; subjective, based on feelings and thoughts. Learning is a lifelong experience and how and what we learn depends on how we feel, our experiences, values and beliefs. Like Neelands (2001) I believe that in order to learn I need to feel safe to experiment, risk, fail, bend and stretch the rules. Therefore it is important to reflect upon my childhood experiences of learning as they will engender and inform my teaching style (consciously and unconsciously). They will further influence how I deal with everyday experiences.

By recognising my unique teaching style and how it has stemmed from my childhood (and other) experiences I can examine aspects of it that I don't like knowing that they are not my fault, just an unexamined response or learned behaviour. This then can lead to me awarding students, colleagues or other people in my life greater tolerance by realising that it is their experiences to date that have shaped their thinking/behavior in this way. I can only share with them my unique ideas and then they choose how to respond to me, just as I choose how to respond to them. As an adult I have more choice because of my greater experience and autonomy. I no longer need to make the same choices that I made as a child and so therefore I can choose to check my initial response, examine it and choose my response. ... (Extract from reply, Week 7:2)

According to Lankshear and Knobel (2004, p. 6) the principle of critical learning is activated when learners develop, experience and negotiate 'differing points of view on social practices, identities, social institutions and the like'. The design and implementation of the reflective task described throughout this paper was facilitated by the necessity to regularly read and write reflectively and responsively. In addition to selectively and reflectively engaging with recommended and required literature, 
students needed to read and reply to one another's responses to that literature. This motivated some students to read more widely and meant that those students who were disinclined or less able to spend the time necessary to engage appreciatively or intellectually with the published literature, were able to connect with that literature through its impact on others. Replying to one another's letters positioned students to read differing responses to the course content and processes - at least 10 others in the course of the semester. This reading of one another's work meant that each student engaged with the literature, directly and/or indirectly, and encountered a range of experiences and points of view - some that resonated with their own and others that offered a different lens.

Alterio (2004, p. 322) notes that: 'When we write and reflect with others we can gain multiple perspectives, although what we learn from our collaborative journaling experiences depends on how well we engage with the reflective process'. Combining the instruction to compose reflections as a letter to a critical friend and replying to a different peer each week, extended what students read, points of interest they addressed and their descriptions of how these connected with prior knowledge and experiences. Over the course of the semester, the online learning system calculation of the number of times individual posts are read, suggested many students routinely read a range of peer reflections beyond what was required for assessment. Making reading interactive by making reflection public and positioning students to respond to one another, not only encouraged reading and writing, but also appeared to extend social networks and personal boundaries. A 'common ground' was created in which members felt a shared commitment to both short and long-term goals necessary to affect transformative learning and evolve a virtual 'community of practice capable of transcending the limits of time and space through technology' (Zeiger \& Pulichino, 2004, p. 3):

Dear critical friend,

What a great sounding reading, you've inspired me to have a look, thank-you. I think that Siegel's (2007) ideas about reflection would support Langer's (2000) ideas about mindful learning. It makes sense to me that if students become more open, self-aware and meta-aware through reflective practice that they are more likely to approach new topics mindfully and engage in mindful learning rather than rote regurgitation. Thus I would try to incorporate reflection into the classroom in the form of discussions. Perhaps even by developing the discussions by following the $\mathrm{P} 4 \mathrm{C}$ approach [referred to in the lecture, details at www. p4c.org.nz] to get students really engaging in thinking and sharing their thoughts and developments with each other so as to scaffold each other's learning.

I would also encourage students to keep a private journal where they chronicle their thoughts or experiences and I (as teacher) flick (but don't read) to see that they have written. I personally believe there is a need for both public and private reflection and think that they serve slightly different aims but are both valuable to develop for our students and for ourselves. See you in class. (Reply, Week 5:2)

\section{Conclusions}

Pivotal to the taking up of the discourses and practices of a reflective practitioner and agent of change is learner recognition of relationships. In particular, the relationships between experiences that constitute and colour our ways of seeing and interacting, information in the form of theory, research and others' points of view. This 
study suggests that incorporating reflection into conventional teacher education course work using asynchronous discussion has the potential to reflectively engage students with one another and relevant information in ways that make connections with past and present and with imagined possible futures. Making conventional components of teaching and learning in higher education the 'what' of reflection seems to have pushed and deepened routine engagement. The genre and the context for the writing - the who and how - pushed students to synthesise and trace connections between various points of view, and constrained those who might otherwise be inclined to simply summarise content under relevant subheadings such as 'readings', 'workshop', etc.

Within the move to the letter-writing genre and to making reflection public, students appeared to talk more directly to one another, sharing experiences, ideas, thoughts about reading, in-class activities and implications for practice. Enabling flexibility of focus and of time for reflection, including opportunities for student choice of selected readings, positioned students to gain confidence in their voice and their ability to respond respectfully and substantively to others. It also meant that, in its entirety, the populated discussion board displayed for both students and teacher the diversity of interests, points of view, aspirations and intellectual engagement across the cohort. The diversity of readings addressed, points expressed and opinions conveyed suggests that building flexibility and choice into the task design, decentred the authoritative voice of the lecturer and the conditioned response of students to look for 'the right answer', the answer they believe the teacher wants to hear. The quality of replies and the expectation that students reply to one another's letters, and in particular to someone previously unknown or unfamiliar to them, seems to reflect the truth in Freire's insight that external discipline creates internal freedom. On a more mundane but pedagogically significant level, replying to one another's letters ensured that each student connected with a range of ideas and information presented in the literature relevant to the course content and processes.

Teaching is an act of intervening Friere (2001). If teachers are to enact the mandates of systemic policy, curriculum and professional standards that call for reflective practice, it is essential that teacher educators intervene to ensure that teachers and would be teachers experience the efficacy of reflection through authentic learning and assessment. As Cumming and Maxwell (1999, p. 179) note: '... it is important to examine carefully the nature of the learning which is anticipated or desired and to tailor the forms of assessment of that learning'. While the sincerity and authenticity of reflection and willingness of students to engage in the process is necessarily skewed by the requirement for assessment (Hobbs, 2007), making reflection public and routine through the use of online forums presents the possibility of activating an authentic learning and assessment process. Including reflective writing as an assessable activity signals to students its value and significance and ensures their attention and commitment to the task requirements.

Further research, debate and description are needed to support teacher educators in their efforts to promote reflective practice as a 'way of being' (Johns, 2005). Each way of being will be subjectively coloured such that the quality of reflection can only be judged by degrees rather than absolutes (Husu et al., 2008). The limitations of the study that informed the description and interpretation of 'who did what and how they went about it' that has been presented throughout this paper, makes it open to contestation and debate. It represents a small part of a much larger story of educators' attempts to understand and enact the potential for reflection to transform practice. 
In their book, Finding a Voice while Learning to Teach, Featherstone, Munby and Russell (1997) note that there is subtle difference between wanting to learn and wanting to be taught that might make a profound difference in the ways that undergraduate teachers approach their course requirements. They suggest that 'Perhaps teacher education programs should be designed with sharing in mind, so that a community of teachers can be established in which we share our experiences, both positive and negative, and support each other in our entry into the profession' (p. 12). Using an online discussion board as the platform for reflection expanded the authenticity of the reflective writing task by expanding the audience and opening the potential for dialogue within and between the social practices required of the task and the discourses and practices conveyed by the community of participants. It appears to have engaged pre-service teachers with wanting to learn and wanting to teach.

\section{Notes on contributor}

Sharn Rocco has been a teacher educator engaged in practising and teaching 'reflection' for more than 20 years. She currently lives on Magnetic Island and works as lecturer in education at James Cook University, Townsville. Recently her interest in the efficacy of reflective practice has extended to researching the teaching of meditation in schools and work places.

\section{References}

Alterio, M. (2004). Collaborative journaling as a professional development tool. Journal of Further and Higher Education, 28, 321-332.

Bowman, B.T. (1989). Self reflection as an element of professionalism. Teachers College Record, 4(4), 335-361.

Brookfield, S. (1995). Becoming a critically reflective teacher. San Francisco: Jossey-Bass.

Cumming, J.J., \& Maxwell, G.S. (1999). Contextualising authentic assessment. Assessment in Education, 6(2), 177-194.

Dewey, J. (1933) How we think: A restatement of the relation of reflective thinking to the educative process. Boston: D.C. Heath.

Featherstone, D., Munby, H., \& Russell, T. (Eds.) (1997). Finding a voice while learning to teach. London: Falmer.

Friere, P. (2001). Pedagogy of freedom, ethics, democracy and civic courage. Maryland: Rowan and Littlefield.

Feidus, H. (1998). Mentoring portfolio development. In M. Lyons (Ed.) With portfolio in hand. New York: Teachers College Press.

Gleaves, A., Walker, C., \& Grey, J. (2008.) Using digital papers and diaries for assessment and learning purposes in higher education: a case study of critical reflection or constrained compliance? Assessment and Evaluation in Higher Education, 33, 219-231.

Gunnlaugson, O. (2007). Shedding light on the underlying forms of transformative learning theory: Introducing three distinct categories of consciousness. Journal of Transformative Education, 5, 134-151.

Hill, L.T., Stremmel, A.J., \& Fu, V.R. (2005). Teaching as inquiry. Rethinking curriculum in early childhood education. Boston: Pearson.

Hobbs, V. (2007). Faking it or hating it: can reflective practice be forced? Reflective Practice, 8, 405-417.

Husu, J., Toom, A., \& Patrikainen, S. (2008). Guided reflection as a means to demonstrate and develop student teachers reflective competencies. Reflective Practice, 9, 37-51.

Johns, C. (2005). Balancing the winds. Reflective Practice, 6, 67-84.

Killen, R. (2007). Effective teaching strategies. Lessons from research and practice (4th ed.). Melbourne: Thomson.

Klein, M. (2008). Holistic reflection in teacher education: issues and strategies. Reflective Practice, 9, 111-121.

Langer, E.J. (2000). The construct of mindfulness. Journal of Social Issues, 56(1), 1-9. 
Lankshear, C., \& Knobel, M. (2004). Planning pedagogy for i-Mode: Some principles for pedagogical decision making. Paper presented at the American Education Research Association Annual Meeting, San Diego, April.

Littky, D. (2002). The big picture education is everyone's business. Virginia: Association for Supervision and Curriculum Development.

Lynch, M. (2000). Against reflexivity as an academic virtue and source of privileged knowledge. Theory Culture and Society, 17(3), 26-54.

McLaughlin, C., \& Lee, M.J.W. (2008). The three P's of pedagogy for the networked society: Personalisation, participation and productivity. International Journal of Teaching and Learning in Higher Education, 20(1), 10-27.

Mezirow, J. (2003). Transformative learning as discourse. Journal of Transformative Education, $1(1), 58-63$.

Neelands, J. (2001). Remember we are human. The Garth Boomer memorial address. AATE/ ALEA Conference. Hobart Tasmania.

O'Hara, M. (2006). In search of the next Enlightenment? The challenge for education in uncertain times. Journal of Transformative Education, 4(2), 105-117.

Paulus, T.M., \& Roberts, G. (2006). Learning through dialogue: Online case studies in educational psychology. Journal of Technology and Teacher Education, 14, 731-751.

Poppo, K. (2006). A pedagogy of compassion: Janusz Korczak and the care of the child. Encounter Education for Meaning and Social Justice, 19, Winter, 33-39.

Queensland College of Teachers (QCT). (2006). Professional standards for Queensland teachers. Toowong, State of Queensland.

Rocco, S. (1999). One day my prince will come. The discursive production of the desire for (heterosexual) marriage. Unpublished doctoral dissertation, James Cook University, Australia.

Schön, D.A. (1983). The reflective practitioner: How professionals think in action. New York: Basic Books.

Siegel, D. (2007). Educating the mind: The fourth ' $\mathrm{R}$ ' and the wisdom of reflection. The mindful brain: Reflection and attunement in the cultivation of well-being. New York: Norton \& Company.

Ukpokodu, O.N. (2008). Teachers reflections on pedagogies that enhance learning in an online course on teaching for equity and social justice. Journal of Interactive Online Learning, 7, 227-255.

Victorian Institute of Teachers (2005). Draft standards for graduating teachers. Melbourne: Victorian Institute of Teachers.

Zieger, L., \& Pulichino, J. (2004). Establishing a community of learners: A case study of a university graduate orientation program for online learners. Journal of Interactive Online Learning, 2(4), 1-13. 